\title{
Determination of Egg Shell Quality with P Control Charts in Poultry
}

\author{
Melis Çelik Güney, Gökhan Tamer Kayaalp* \\ Department of Animal Science, Agriculture Faculty, Çukurova University, 01330 Adana, Turkey
}

\begin{tabular}{l}
\hline A R T I C L E I N F O \\
\hline Article history: \\
Received 03 May 2016 \\
Accepted 20 May 2016 \\
Available online, ISSN: 2148-127X
\end{tabular}

Keywords:

Statistical quality control

$\mathrm{P}$ control chart

Egg shell quality

U Control chart

Binomial distribution

\begin{abstract}
A B S T R A C T
Broken or cracked eggs are important factor in determining the quality of the egg shell. Manufacturers are experience great losses because broken or cracked eggs aren't evaluated. The manufacturers need control charts throughout the production to determine whether process is under control. In this study, broken and cracked eggs which are taken Cukurova University, Faculty of Agriculture, Department of Animal Science, Poultry Businesses during 52 weeks are determined. P control charts of the data's are taken in poultry business during 52 weeks is drawn due to determining whether there is under the control. Three methods were used for drawing control charts. In the end of this study, it has been determined to be not under control of the process.
\end{abstract}

${ }^{*}$ Corresponding Author:

E-mail: tkayaalp@cu.edu.tr

\section{Introduction}

The quality of egg shell is very important factor for poultry. There are numerous factors which are affected the development of shell like age, temperature, nutrition and health status of chicken besides common factor like chicken's genotype (Roberts, 2004).

Economic losses occur due to broken and cracked eggs. At the same time, this is loss of protein for growing population have needed for their health (Çetin and Gürcan, 2006).

Even if the loss in egg sector aren't prevent, it can be reduced by producers. Also producers should take measures by determining to unexpected change. If producers don't take measures, sale decrease in business. Because of this, producers started to care quality control more. Statistical quality control charts have been used mostly in quality control method.

Control charts show change of measurement value have been taken periodically in time (TÜIK, 2011). The purpose of the control chart is to show how processes are executed (Bircan and Gedik, 2003). The process is events are repeating, developing, advancing during production in the time. Control charts indicate that productions whether it remain in control limits and if it exceed the control limits, the control charts provide again into the control limits by alerting.

The aim of this study is to determine the process whether it has been under controlled throughout 52 week, with the aid of control charts by taking broken and cracked eggs.

\section{Material and Methods}

In the study, eggs are used as material which taken from Cukurova University, Faculty of Agriculture, Department of Animal Science, Poultry Business. The eggs are produced by chickens are analysed rate of broken and cracked eggs from 25 th week to 76 th week. If the eggs have been taken are broken and cracked, they are described as defective. Microsoft Excel 2010 V. software were used for evaluating the data and drawing graphics.

Control charts are divided into two groups as qualitative and quantitative (Ertuğrul and Özçil, 2013). It is possible that quality characteristic is determined on qualitative control charts by sense of organs. They are used quality characteristic such as broken, cracked, damaged, stained, rough. These are $\mathrm{p}$ control chart, np control chart, c control chart and u control chart (Çolak, 2007).

If one defective item is sufficient to be rejected, $p$ control chart is used. However, if the aim is to measure the number of defects in the accumulation of production, c control chart is used (Demir and Gümüşoğlu, 2003). In some cases, number of defect in one unit is paid attention to the instead of the produced products are defective or not. U control chart is used in this case (Ertuğrul and Karakaşoğlu, 2006).

There are three lines are on the basis of control charts. These are "Upper Control Limit", "Center Line" and "Lower Control Limit". If all marked spots on control charts are in control limits, this means that process is called "statistical control", "under control" or "statistical 
balance". If which one of them is out of control limits, this means that process is called "not under control" or "not statistical balance" (Neave and Wheeler, 1996).

The first of following step for creating both qualitative control chart and quantitative control chart is to determine quality characteristics. After that it is sampled with certain sampling method. The types of control chart and control limits are determined. Then, limits are charted. Lastly, points which exceed the limits are controlled.

In this study, p control charts was used as method. Control limits were determined by using three different methods since sample size is not equal. As a result of this, process was to determine whether it is under control.

\section{Qualitative Control Charts}

$P$ control charts: $\mathrm{P}$ control chart controls the process by paying attention to the rate of defective during the production process. Defective rate is calculated dividing the total number of defective product by the total number of sample size.

$\mathrm{P}$ control charts are assumed to be binomial distribution. Only if the sample size is so much, the binomial distribution is approximately normal distribution (Stevenson, 1993). The probability function of binomial distribution is shown following:

$$
P\{X=x\}=\left(\begin{array}{l}
n \\
x
\end{array}\right) p^{x}(1-p)^{n-x} \quad x=0,1,2, \ldots, n
$$

$$
\begin{aligned}
& \text { Where: } \\
& \mathrm{n}=\text { Sample size } \\
& \mathrm{p}=\text { Defective rate } \\
& \mathrm{x}=\text { Number of defective }
\end{aligned}
$$

The center line on $\mathrm{p}$ control chart shows the average of defective rate. If examples are been under this line, defective rate is low. When the point of the center line to be regularly distributed, it can mean as improvement in quality. Value under of lower control line shows that defective rate where is belong sample is very low. However, it shouldn't be evaluated as improving the quality immediately (Ertuğrul, 2004).

If sample size is not equal, three method are used to determine whether the process is under control with $p$ control charts. The first method is used if the largest sample sizes don't exceed the smallest sample size more than 20\% (Başkan, 1996). Control limits used for this method is calculated by the following formula (Montgomery, 1990; Ertuğrul and Karakaşoğlu, 2006).

$$
\begin{aligned}
& \widehat{\mathrm{P}}=\frac{\mathrm{D}}{\mathrm{n}} \quad \overline{\mathrm{P}}=\frac{\sum_{\mathrm{i}=1}^{\mathrm{n}} \mathrm{D}_{\mathrm{i}}}{\sum_{\mathrm{i}=1}^{\mathrm{n}} \mathrm{n}_{\mathrm{i}}} \quad(\mathrm{i}=1,2, \ldots \mathrm{k}) \\
& \overline{\mathrm{n}}=\frac{\sum_{i=1}^{n} \mathrm{n}_{\mathrm{i}}}{k} \quad(\mathrm{i}=1,2, \ldots, \mathrm{k}) \\
& \mathrm{UCL}=\overline{\mathrm{P}}+3 \sqrt{\frac{\overline{\mathrm{P}(1-\overline{\mathrm{P}})}}{\overline{\mathrm{n}}}} \\
& \mathrm{CL}=\overline{\mathrm{P}} \\
& \mathrm{LCL}=\overline{\mathrm{P}}-3 \sqrt{\frac{\overline{\mathrm{P}}(1-\overline{\mathrm{P}})}{\overline{\mathrm{n}}}}
\end{aligned}
$$

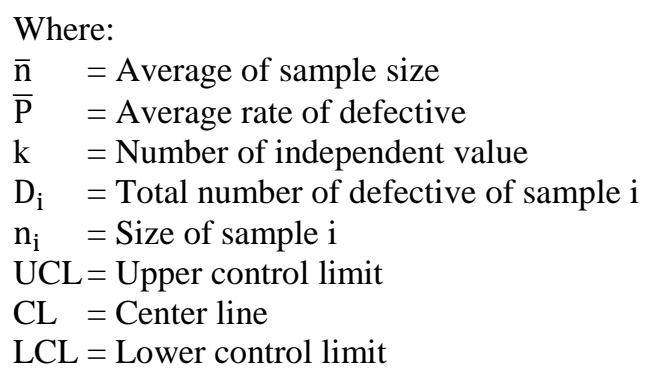

If the largest sample size exceeds the smallest sample size more than 20\%, control limits are determined separately for each subgroup. Defective rate are shown on the graph (Başkan, 1996). Control limits used for this method is calculated by the following formula (Montgomery, 1990; Ertuğrul and Karakaşoğlu, 2006).

$$
\begin{aligned}
& \mathrm{UCL}=\overline{\mathrm{P}}+3 \sqrt{\frac{\overline{\mathrm{P}}(1-\overline{\mathrm{P}})}{\mathrm{n}_{\mathrm{i}}}} \\
& \mathrm{CL}=\overline{\mathrm{P}} \\
& \mathrm{LCL}=\overline{\mathrm{P}}-3 \sqrt{\frac{\overline{\mathrm{P}}(1-\overline{\mathrm{P}})}{\mathrm{n}_{\mathrm{i}}}}
\end{aligned}
$$

The other method used when the largest sample size exceeds the smallest sample size more than 20\%, standardized values are calculated for each week. Standardized values are shown on the graph. Upper control limit for the value is taken +3 , the center line is taken 0, lower control limit is taken -3 (Başkan, 1996). This method are used with the following formula (Montgomery, 1990; Ertuğrul and Karakaşoğlu, 2006).

$$
\mathrm{Z}_{\mathrm{i}}=\frac{\widehat{\mathrm{P} 1}-\widehat{\mathrm{P}}}{\sqrt{\frac{\overline{\mathrm{P}}(1-\overline{\mathrm{P}})}{\mathrm{n}_{\mathrm{i}}}}} \sim \mathrm{N}_{\mathrm{z}}(0,1)
$$

\section{Results}

The eggs are collected from Cukurova University, Faculty of Agriculture, Department of Animal Science, Poultry Business for looking at the broken and cracked of rate. It has been created $\mathrm{p}$ control chart by used them. Data received from the poultry business:

The total number of defective is $\left(\sum_{\mathrm{i}=1}^{\mathrm{n}} \mathrm{D}_{\mathrm{i}}\right) ; 11880$.

The total sample size is $\left(\sum_{\mathrm{i}=1}^{\mathrm{n}} \mathrm{n}_{\mathrm{i}}\right) 1129180$.

First week, 165 eggs are defective in 23200 eggs $\left(\mathrm{n}_{1}=23200, \mathrm{D}_{1}=165\right)$.

Firstly, maximum and minimum sample are determined. The largest sample size $\left(\mathrm{n}_{\max }\right)$ is 31000 , the smallest sample size $\left(\mathrm{n}_{\min }\right)$ is 12000 . It is seen that 31000 $\geq \frac{120}{100} * 12000$. That is, the largest sample size exceeds the smallest sample size more than $20 \%$. In this case, the determination of limit control is not recommended according to the formula given (2). The formulas given number (3) or number (4) can be used. 
If the largest sample size exceeds the smallest sample size more than 20\%, control limits are determined separately for each subgroup. Upper control limit, center line and lower control limit were solved for the first week as below by using the formula given (3).

$$
\begin{aligned}
& \bar{P}=\frac{11880}{1129180}=0.0105 \\
& \mathrm{UCL}=0.0105+3 \sqrt{\frac{0.0105 *(1-0.0105)}{23200}}=0.0125 \\
& \mathrm{CL}=0.0105 \\
& \mathrm{LCL}=0.0105-3 \sqrt{\frac{0.0105 *(1-0.0105)}{23200}}=0.0085
\end{aligned}
$$

When determining the limit control for the other weeks, upper control limit, center line and lower control limit should be determined for each week by changing only the value $\mathrm{n}_{\mathrm{i}}$. Drawn graph according to limits calculated during 52 weeks is given Figure 1.

Figure 1 show the calculation of the different control limits for each week. Process is not under control due to week exceeded the control limits.

The other method used when the largest sample size exceeds the smallest sample size more than 20\%, standardized values are calculated for each week. $Z_{i}$ value is given for the first week as below by using the formule given (4).

$$
P_{i}=\frac{D_{i}}{n_{i}}
$$

Defective rate for the first week;

$$
\begin{aligned}
& \mathrm{P}_{1}=\frac{165}{23200}=0.00711 . \\
& \mathrm{Z}_{1}=\frac{0.00711-0.0105}{\sqrt{\frac{0.0105(1-0.0105)}{23200}}}=-5.06
\end{aligned}
$$

When determining the limit control for the other weeks, standardized values should be determined for each week by changing only the value $\widehat{P}_{1}$ ve $n_{i}$. Drawn graph according to standardized values calculated during 52 weeks is given Figure 2.

\section{Discussion}

Eggs have been from poultry business during 52 weeks were examined by forming p control chart. In the first weeks, points have remained below the lower control limit lines. Defective egg ratio is in critical point in the whole process when look $\mathrm{Z}$ account of value. Because, eggs are collected in business for the sale weekly, broken or cracked eggs is low rate in the fist weeks and this situation doesn't affect the company adversely (Figure 2). Broken and cracked rate of the eggs is too much after 40 week (Figure 1 and Figure 2). Causes of this situation out of control must be investigated, whatever necessary must be done. As a result, the losses of eggs have been produced for consumer will reduce and rate of broken and cracked eggs the passing into the hands of consumers will reduce. Manufacturing cost will decrease, income will increase and also the quality of the eggs will be ensure.

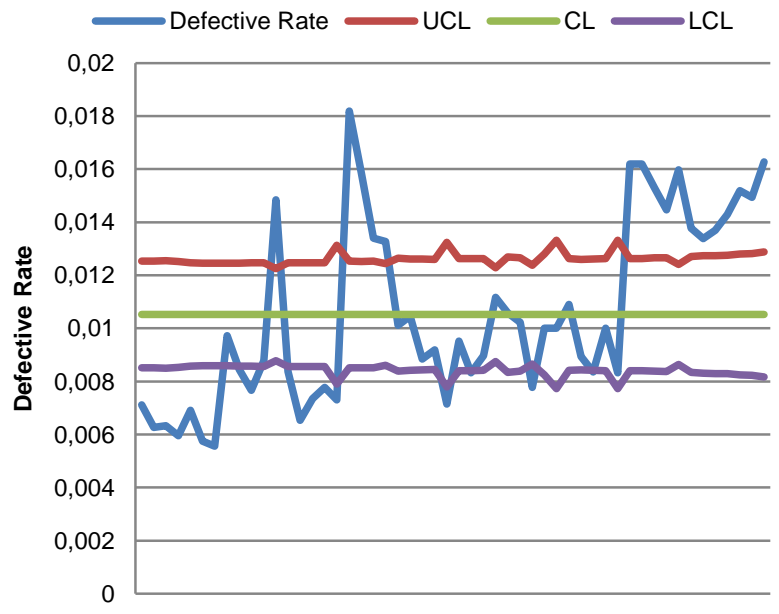

Figure 1 Defective rate graph
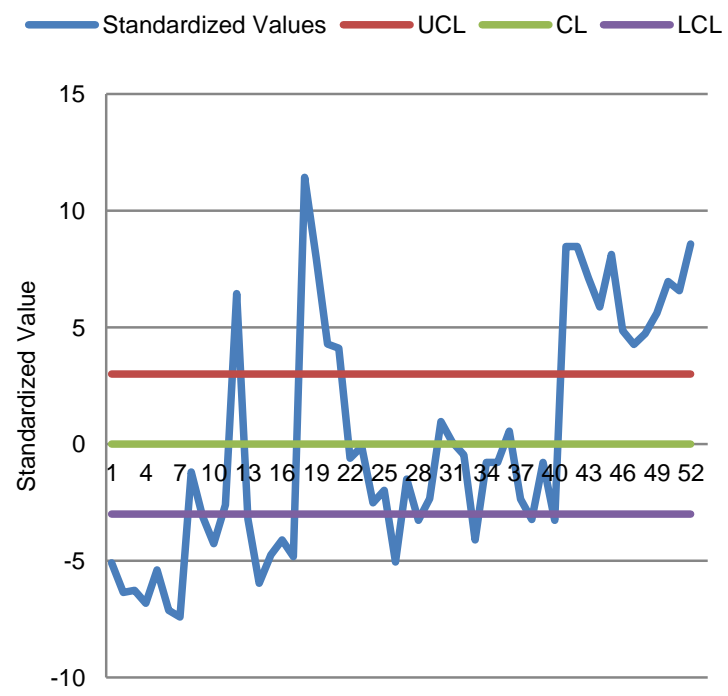

Figure 2 Defective rate graph of standardized

\section{References}

Başkan S. 1996. İstatistiksel Kalite Kontrol Yöntemleri. Ege Üniversitesi Yayınevi, İzmir.

Bircan H, Gedik H. 2003. Tekstil Sektöründe İstatistiksel Proses Kontrol Teknikleri Uygulamas1 Üzerine Bir Deneme. C.Ü. İktisadi ve İdari Bilimler Dergisi, 4(2): 69-79.

Çetin S, Gürcan S. 2006. Kahverengi ve Beyaz Yumurtacı Hibrit Tavuk Yemlerine İstiritye Kabuğu İlavesinin Yumurta Kabuk Kalitesine ve Serum Kalsiyum Düzeyine Etkileri. Lalahan Hayvancılık Araştırma Enstitüsü Dergisi. 46(2): 23-31.

Çolak T. 2007. İstatistiksel Süreç Kontrolü ve Uygulamalar. Çukurova Üniversitesi, Fen Bilimleri Enstitüsü Yüksek Lisans Tezi, Adana.

Demir H, Gümüşoğlu S. 2003. Üretim Yönetimi. Beta Basım Yayın Dağıtım, İstanbul.

Ertuğrul İ. 2004, Toplam Kalite Kontrol ve Teknikleri. Ekin Kitabevi, Bursa.

Ertuğrul İ, Karakaşoğlu N. 2006. Kalite Kontrolde Örneklem Büyüklüğünün Değişken Olması Durumunda $\mathrm{p}$ Kontrol Şemalarının Oluşturulması. İstanbul Ticaret Üniversitesi Fen Bilimleri Dergisi, 5(10): 65-80. 
Ertuğrul İ, Özçil A. 2013. The Application Of 'p' and 'p-CUSUM' Charts Into Textile Sector in The Statistical Quality Control Process. Tekstil ve Konfeksiyon. 24 (1):9-14.

Montgomery DC. 1990. Introduction to Statistical Quality Control. J. Wiley and Sons Inc. k, Canada.

Neave HR, Wheeler DJ. 1996. Shewhart's Charts and The Probability Approach. Ninth Annual Conference of the British Deming Association, London.
Roberts J. 2004. Factors Affecting Egg Internal Quality and Egg Shell Quality in Laying Hens. Journal of Poultry Science, 41: 161-177.

Stevenson WJ. 1993. Production / Operations Management, Irwin Inc., USA.

Türkiye İstatistik Kurumu (Tüik). 2011. İstatistiksel Kalite Kontrol. Sorularla Resmi İstatistikler Dizisi-11, Ankara. 